\title{
WestVirginiaUniversity
}

THE RESEARCH REPOSITORY @ WVU

Graduate Theses, Dissertations, and Problem Reports

2000

\section{Fundamental analysis of price on Chinese steel products}

Jiang Xia

West Virginia University

Follow this and additional works at: https://researchrepository.wvu.edu/etd

\section{Recommended Citation}

Xia, Jiang, "Fundamental analysis of price on Chinese steel products" (2000). Graduate Theses, Dissertations, and Problem Reports. 825.

https://researchrepository.wvu.edu/etd/825

This Thesis is protected by copyright and/or related rights. It has been brought to you by the The Research Repository @ WVU with permission from the rights-holder(s). You are free to use this Thesis in any way that is permitted by the copyright and related rights legislation that applies to your use. For other uses you must obtain permission from the rights-holder(s) directly, unless additional rights are indicated by a Creative Commons license in the record and/ or on the work itself. This Thesis has been accepted for inclusion in WVU Graduate Theses, Dissertations, and Problem Reports collection by an authorized administrator of The Research Repository @ WVU. For more information, please contact researchrepository@mail.wvu.edu. 


\title{
Fundamental Analysis of Price on Chinese Steel Products
}

\author{
Jiang Xia \\ Thesis Submitted to \\ College of Business and Economics \\ At West Virginia University \\ In partial fulfillment of the requirements \\ For the degree of \\ Master of Arts \\ In \\ Economics \\ K. Victor Chow, Ph.D., Chair \\ William Trumbull, Ph.D. \\ Ming-jeng Hwang, Ph.D. \\ Department of Economics \\ Morgantown, West Virginia \\ 2000
}

Keyword: Steel Price, Economic Reform, Factor Analysis. 


\section{ABSTRACT \\ Fundamental Analysis of Price on Chinese Steel Products \\ Jiang Xia}

The analysis of the determination of steel prices is of great importance particularly for the formulation of economic policy in less developed countries. Five fundamental factors influencing price of steel products are examined. A hedonic function which reflects the relation between prices of varieties or models of heterogeneous goods and the quantities of characteristics has been used and empirical tests applied to this function has been done using 1978-1998 Chinese annul data. Results are with the trend toward globalization China will become more market oriented and the factors analyzed in the paper would pay key role in determining Chinese steel products prices. 


\section{TABLE OF CONTENTS}

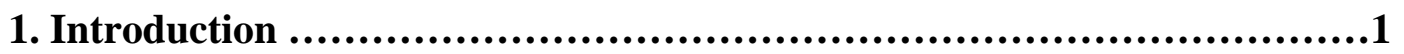

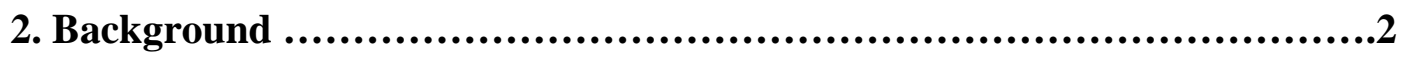

3. Fundamental Factors Influencing Price of Steel Products ....................5

3.1 Overall Price Level .................................................6

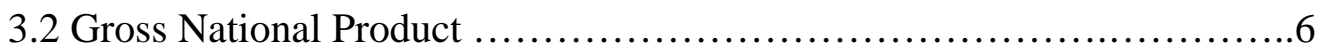

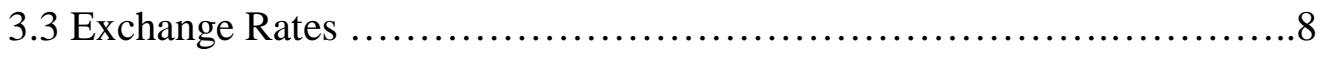

3.4 Interest Rates .................................................... 9

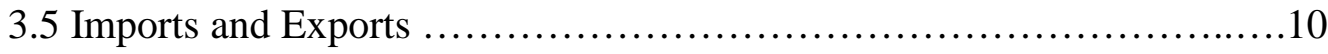

4. Price Model-Hedonic Price Indexes and Analysis ............................12

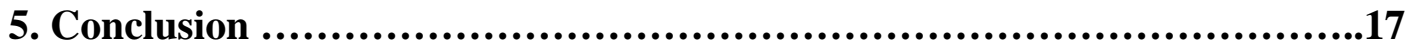

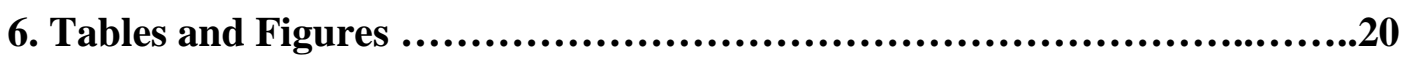

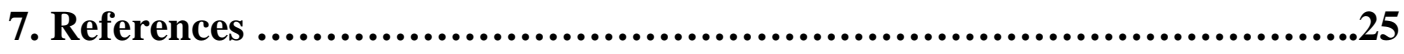




\section{Introduction}

Steel products are among the most important intermediate products in the world today. Steel production is an important indicator for judging the industrialization level of a country. The analysis of the determination of steel prices is of great practical importance, particularly for the formulation of economic policy in less-developed countries. Steel prices are volatile. (Chinese steel prices experienced a sharp rise in 1993 followed by a steep decline after prices were deregulated.) For countries whose export earnings and GNP are dependent on this commodity, such volatility poses major problems on both macroeconomic and microeconomic policies. (Angus Deaton, 1992). A thorough understanding of the factors that influences price movements is essential for rational economic decision making.

I work in one of the major Chinese steel enterprises. The purpose of this paper is to identify the main economic fundamentals behind the behavior of steel prices so as to provide policy recommendations to steel enterprises and the government.

This thesis is organized as follows: Section 2 discusses the history of the steel market in China and the changes in steel prices that have occurred over the post years. Section 3 analyzes the factors that affect the price of steel products. Section 4 uses Hedonic methods to derive a model of the price indices for steel products which can be used to (1) predict the price of steel products and (2) examine empirically how each factor influences steel prices using Chinese annual data from 1978 to 1998. Section 5 provides a summary and conclusions. 


\section{Background}

Pricing of Chinese steel products exhibited different characteristics in different stages of economic development in China.

After the founding of the People's Republic of China in 1949, to promote the recovery of the national economy and to stabilize the market and commodity prices, a low price policy for steel products was followed at the unified ex-factory price. The government practiced a strict management plan. This policy fueled a rapid recovery and development of follow-up industries with favorable results for a short period.

During the following 30 years, the Chinese government practiced centralized economy planning. Prices of steel products were strictly controlled by the state; each enterprise had no right to determine prices. Prices operated under the influence of the traditional theory that the means of production are not commodities and thus market price adjustments are not allowed. The system of highly centralized price management did not conform to economic signals from the beginning and prices could not therefore change with changes in supply and demand. A market price allocation system could not be developed. This eventually caused serious market distortions with long term shortages of steel products, and "bottlenecks" in production. The pricing structure stimulated blind development of follow-up processing industries, resulting in an unreasonable allocation of resources to these down-line industries and a phenomenon of coexisting shortages and surpluses. 
On May 10, 1984, the Chinese State Council issued a decision which granted the right of state industrial enterprises to make further expansions "which marked the formation of a double price system" with a state price and a market adjustment price coexisting at same time and place for the same product. Revisions were made in the following years regarding the management and scope of this measure. These procedures improved the price structure of steel products to a certain degree. With the formation of the double price system, the percentage of steel produced within the plan became smaller and that produced outside the plan became larger. The problem of an unbalanced industrial structure became more serious. Abnormally low prices of products within the plan and abnormally high prices for products outside the plan emerged and the magnitude of the difference increased over time.

In 1992, price reform of steel products provided a further step forward. Guided by "the policy of change class, float, combine and lift control", an important reform was made on the pricing mechanism. First class steel products were all changed into second class prices. Second class prices were changed into state guided prices plus or minus $10 \%$. The price of special steel products was partly combined and partly decontrolled. Maximum limit prices of products not included in the plan were removed.

On January 1, 1993, the prices of steel products, except for special steel products used by railway and military industries, were decontrolled by the state. The pricing of most products was transferred to firms. In the second half year of $1993,97 \%$ of steel products were traded according to market prices. Transformation from state pricing of the planned economy to enterprise pricing of the market economy was finally realized with the price reforms that took place in 1993. When price controls of steel products 
were lifted in 1993, the economy was in an over-heated state. Prices of steel products were influenced by too little fixed asset investment and speculation rose rapidly. The higher price of steel enabled steel enterprises to digest rapid increases in the price of materials and fuels, provided firms with capital to acquire new equipment, product type and quality, and greatly increase production scale. In 1994, Chinese steel output ranked among the highest in the world. However, the high price brought a series of negative effects. First, it contributed to inflation by increasing the cost of steel products. Secondly, it stimulated large increases of imports. Sixty-two million tons of steel were imported in 1993 and 1994. Third, it stimulated investments in small blast furnaces and small roller production in local enterprises. The cost of their products was high but quality was low. In the past, low quality steel products has negatively influenced the reputation of the Chinese domestic steel industry. Some large enterprises invested in long-line production with inferior technology. By 1997, there was 17-18 million tons of excess capacity. Fourth, the initial high price and high sales resulted in some enterprises being poorly managed. The expansion of production capacity and increased imports initially increased supply but demand subsequently decreased. As the price of steel products began to drop from the second half of 1993, profits in the steel industry decreased abruptly, placing many enterprises in a very difficult situation. Some high value-added products had to depend on imports. Normally China imports 14 million tons per year of steel products (78 million tons are products which China is unable to produce domestically).

The history of Chinese steel pricing reveals the need for a pricing structure which is based on market forces. Fortunately the Chinese government and leaders in the steel 
industry realized this and have been willing to allow the steel industry to move from an industry controlled through central planning to an industry responding to market forces. It is not enough to simply observe what is happening, it is more important to analyze how the market economy works for the steel industry and what factors explain the price of steel products. Corporate decisions can only be made with a thorough understanding of the forces influencing steel prices. Section 3 examines the fundamental factors influencing the price of steel products.

\section{Fundamental Factors Influencing The Price of Steel Products}

We know that demand and supply together determine a commodity's price. When the market is clear (Demand equals supply) an equilibrium price is achieved. Changes in either demand or supply affect this equilibrium price. We observe price decreasing when supply is greater than demand and price increasing vise visa. Studies that have stressed a structural approach to commodity price determination have found that two (demand-side) variables did well in explaining the variation of the commodity prices: the state of the business cycle and the real exchange rate. By late 1984 the demand driven models began systematically to over-predict real commodity prices. This suggested that more important variables were being left out of the analysis (Eduardo Borensztein \& Carmen M. Reinhart, 1994). Research explains the origin of the observed coincidence of commodity price variations with the fluctuations of macroeconomic variables such as industrial production, overall price level, exchange rates, interest rates and imports and exports (Ping Hua, 1998). 


\subsection{Overall Price Level}

The economy's price level is the price of a broad reference basket of goods and services. A rapidly developing national economy increases market demand and makes prices rise. The rise of industrial product prices forms a cost-push effect on the general price level. If the overall price level rises, individual households and firms must spend more money than before to purchase their usual weekly market baskets of goods and services. Economic growth increases inflation rates and the production costs of commodities. As a result commodity prices increase too.

Figure 3-1 shows the relationship between total commodity prices and the price of steel products. There is a positive relationship between the overall price level and the price of steel products. In the years 1984-1995, the price indexes for commodities increased from 116 to 331 and the price indexes of steel products increased from 117 to 427. This relationship occurs because the price of steel products rise with an increase in costs when commodity prices rise and with the excess demand for steel products.

\subsection{Economic Growth (Gross National Product)}

Economic growth is the expansion of the economy's production possibilities. The gross national product (GNP) is among the most important social statistics for a society. GNP is a summary measure of total output in an economy and is often used as a measure of social welfare. It has been used to develop aggregate productivity measures in economic development and is often an important determinant of demand for the products of individual firms. Economic growth is measured by the increase in real gross national product. China has long reported gross national product (GNP) as its primary measure of 
national economic activity.

We are interested in economic growth because to some extent it offers us the explanation of steel prices from the demand side. Different levels of economic development cause different demands for commodities. Developed countries all experience high demand for steel products. In the middle stage of development when a economy takes off, the scale of fixed asset investment is large, consumption of steel products is high, demand for steel products is at a high level, however, increases in supply is relatively slow, customs duties are high, prices and profit rates are relatively high. After a country enters into a mature industrialization stage, demand for steel products is no longer at its peak and excess production capacity often exists in the industry. More attention is paid to optimization of product structure with an increase in the production of upgraded products with high additional value. So the domestic price decreases and the steel industry has only minimal profit.

From Figure 3-1 we see that while most parts of the developing world experienced a 'lost decade', and countries of the former Soviet bloc struggled to cope with a great depression, the Chinese economy continued to grow at a rapid pace. Between 1978 and 1998, the country's gross national product, on average, grew by 9.5 per cent in real terms per annum (Figure 3-1.) We observe a positive relationship between the GNP and the price index of steel products(Figure 3-2). The increases in GNP will raise the demand for steel products, which increases the prices of steel products. 


\subsection{Exchange rate}

The exchange rate for a currency is its price in the terms of another currency. Households and firms use exchange rates to translate foreign prices into domestic currency terms. Once the prices of domestic goods and imports have been expressed in terms of the domestic currency, household and firms can compute the relative prices that affect international trade flows.

Ridler and Yande(1972) originally developed a simplified model for analyzing the effects of exchange rate changes on the prices of primary commodities. This idea is accepted and further developed by many researchers like Sachs(1985), Dornbusch(1985), Radetzki(1985), Adams and Vial(1988), Gilbert(1989), Hua and Collange(1994). A real "appreciation" of a country's currency may lead immediately to an increase in local relative prices of commodities in other countries if the purchasing power parities are not maintained in the concerned countries. Foreign demand for commodities may decrease and foreign supply may rise. This may lead to a decrease in commodity prices in world commodity markets. Conversely a real "depreciation" may result in an increase in world commodity prices.

Furthermore, steel product prices could also be affected by changes in the exchange rate of other related countries. Because we are in a world-wide economy it is obvious that other countries' economic status could affect our own country. Here is an example. There was a high variability in the exchange rates of the Japanese yen and the US dollar over the period considered in this thesis. Changes in exchange rates were particularly important over the period $1978-1998$, with the Japanese yen, in particular, experiencing a major depreciation against the US dollar. Our interest in analyzing the 
role of exchange rates on the pricing model of steel is reinforced by the findings of an analysis of the surveys of steel price differentials in China. Figure 3-3 shows that there is a clear correlation between currency fluctuations and changes in the relative price levels of steel products. That is, as the currency of Japan depreciates against the currency of US, the unit cost of Japan's exports decline, thus increasing the volume of its exports which results in the lower prices of steel products in China.

\subsection{Interest rates}

Theoretically, interest rates also have a great influence on price. The real interest rates represent the opportunity cost of holding commodities either as one part of inventory costs or as portfolio assets. If interest rates become high, the cost of commodity inventories are immediately more expensive. This causes the demand for primary commodities to fall. High interest rates may also affect commodity prices either via the substitution effects of reducing investment in favor of increasing savings(Hua, 1994), or via the flight of capital from developing countries (Rausser et al., 1990)

Figure 3-4 shows the relationship between interest rates and the price index of steel products. The interest rates in 1982-1984 were $7 \%$ and the price indexes of steel products ranged from 111 to 117 . Interest rate in 1998 also was 7\%, while the price index of steel products was 346 . The interest rate was $9 \%$ in 1988 while the price index of steel products was 177, and the interest rate was $9 \%$ in 1997 while the price index of steel products was 375 . It appears that the interest rates do not have a great influence on the price of steel products. This is a special condition under the command economy. The central bank of China kept the interest rates fixed in order to maintain a stable market. 


\subsection{Imports and Exports}

The economies of all nations are linked to one another through a complex network of trade and financial relationships. International trade is an important element in virtually every economy. In some nations it may represent as much as one-fourth of the total national product. Present world production of steel is higher than demand. Steel companies around the world typically earn low profits. To protect the steel industry, price restrictions are used by some organizations. For example, the European Steel Union limits output to maintain prices. Under such circumstances, all countries, especially developed countries have a strong desire to export steel products and to develop a foreign market. China is one of their main targets.

Developed countries are major suppliers of steel products on the world market and have surplus production capacity, high productivity, advanced production techniques, high management level and low cost and price. Additionally, some modernized large enterprises such as Nippon Steel Corporation have convenient foreign resources and transportation. Steel products on the world market have a higher quality than Chinese products. The Chinese steel industry is facing a severe test. To maintain its market share and adequate profits, it must compete actively.

When one country imports products, these imports enter the economy to compete in markets with domestically produced goods. The domestic price of the product will tend to fall, and profit, as well as volume of sales, are likely to suffer. Therefore, output and employment in this import-competing industry are likely to fall. While output and employment fall in the import-related industry, the supply of steel products increases 
which results in decreases in the price of steel products. Consequently, output and employment tend to rise in the exporting industries of the country, as the money that is used to pay for imports eventually is funneled back into the country for investment or for the acquisition of products and services. The domestic price of steel products will tend to rise.

In China after price controls of metallurgical products were lifted in 1993, multiple factors stimulated sudden increases in demand. A shortage in supply stimulated an abrupt rise in domestic market prices. Large price differences between domestic and world prices made importing steel highly profitable. In 1993, there were 30.26 million tons of steel products imported. The total value of 10.71 million tons or $35.4 \%$ of steel wire, were imported with a value of 11,100 million US dollars, steel imports accounted for $13.98 \%$ of total imports and $28.49 \%$ of consumption, the highest amounts in history. A total of 53.09 million tons of steel products were imported in 1993 and 1994. The price difference between domestic and world markets was the main factor in this high level imports.

A large price disparity between domestic and world prices causes a high level of imports. Generally speaking, high imports leads to an excess of supply in the domestic market, an increase of inventory, and a fall in price. However, Figure 3-5 does not show that there is a negative relationship between the imports and the price of steel products. Figure 3-6 shows the relationship between the steel exports and the price of steel products. The graph suggests that an increase of exports will result in a decrease in the quantities of supply in the domestic market, which results in an increase in the domestic price in steel products. Higher net imports are associated with lower domestic prices, but 
there is significant variability within the data set. Figure 3-7 shows the relationships between the ratio of imports and exports and the prices of steel products for the period 1978-1998.

\section{Price Model-Hedonic Price Indexes and analysis}

A hedonic price index is one that makes use of information from the hedonic function. Adding time dummy variables to a multi-period regression on the hedonic function is a widely used empirical procedure. A hedonic function reflects the relation between prices of varieties or models of heterogeneous goods (services) and the quantities of characteristics contained in them: (Blackorby, C., Primont, D. and Russell, R.R.1978, Duality, Separability and Functional Structure)

$$
P=h(c)
$$

Where $\mathrm{P}$ is an n-element vector of prices of varieties, and (c) is a $k \times n$ matrix of characteristics. The theory providing its economic interpretation rests on the hedonic hypothesis that heterogeneous goods are aggregations of characteristics, and economic behavior relates to these characteristics. A characteristic price index is any index that is defined on the characteristics of goods, or on behavioral functions in which characteristics are arguments. A hedonic price index is thus a particular implementation of a characteristic price index. Almost any empirical application of hedonic functions 
\(e.g. use of hedonic wage regressions to estimate race or sex discrimination in labor markets) can be interpreted as an index number, so the theory of characteristics-space indexes has wide applicability. The following is couched in terms of a price index of steel products. The price index between period's $t$ and $t-1$ is then:

$$
\frac{P_{t}}{P_{t-1}}=\frac{A_{t}}{A_{t-1}} \times \frac{B_{t}}{B_{t-1}} \times \frac{C_{t}}{C_{t-1}} \times \frac{D_{t}}{D_{t-1}} \times \frac{E_{t}}{E_{t-1}}
$$

$\Delta P_{t}=\alpha_{t}+\beta_{t} \Delta A_{t}+\delta_{t} \Delta B_{t}+\varepsilon_{t} \Delta C_{t}+\gamma_{t} \Delta D_{t}+\lambda_{t} \Delta E_{t}+\mu_{t}$

Where $\Delta P_{t}=\operatorname{Ln} P_{t}-\operatorname{Ln} P_{t-1}$, the change of price index of steel products;

$\Delta A_{t}=\operatorname{Ln} A_{t}-\operatorname{Ln} A_{t-1}$, the change of total price index;

$\Delta B_{t}=\operatorname{Ln} B_{t}-\operatorname{Ln} B_{t-1}$, the change of GNP;

$\Delta C_{t}=\operatorname{Ln} C_{t}-\operatorname{Ln} C_{t-1}$, the change of exchange rates;

$\Delta D_{t}=\operatorname{Ln} D_{t}-\operatorname{Ln} D_{t-1}$, the change of interest rates;

$\Delta E_{t}=\operatorname{Ln} E_{t}-\operatorname{Ln} E_{t-1}$, the change of the ratio of imports and exports;

$\alpha_{\mathrm{t}}, \beta_{\mathrm{t}}, \delta_{\mathrm{t}}, \varepsilon_{\mathrm{t}}, \gamma_{\mathrm{t}}, \lambda_{\mathrm{t}}=$ coefficients;

$\mu_{\mathrm{t}}=$ noise.

The performance of China's economy over the period 1978-1998 has been described. We take the regression of equation 3-2 on figure 3-1 by least square method. The null hypothesis is that the coefficients of right hand side variables in equation 3-2 are 
zero. The following results were obtained:

\begin{tabular}{|l|c|c|c|}
\hline Variable & Parameter Estimate & T For $\mathrm{H}_{0}=0$ & Prob $>|\mathbf{T}|$ \\
\hline$\alpha$ & -0.012651 & -0.346 & 0.7347 \\
\hline$\beta$ & 0.186467 & 0.700 & 0.4955 \\
\hline$\delta$ & 0.369883 & 1.276 & 0.2227 \\
\hline$\varepsilon$ & -0.154133 & -1.231 & 0.2385 \\
\hline$\gamma$ & 0.108321 & 1.091 & 0.2937 \\
\hline$\lambda$ & -0.034783 & -2.759 & 0.0154 \\
\hline
\end{tabular}

$\mathrm{R}$ square is 0.6298 for this regression which is not bad. Our results explain more than 60 percent of the variation in the data. After checking the eigenvalues of the $x^{\prime} x$ (regresses) matrix, the conditional index is far less than 20 which tells us that there is no multicollinearity in this regression.

First we analyze the influence of the change of price index on the price of steel products. From table 1 we can see that the estimated value of coefficient $\Delta A_{t}$ is positive. As hypothesized, the regression shows that the higher the price indexes, the higher the steel price. Higher price index increase the inflation rates and the production costs and as a result commodity prices increases too. So this positive relationship is reasonable here but as we noticed, the effect of the overall price level is not significant on steel products prices for the Chinese data we used. So the price index does not explain much about the changes of steel products prices in China.

Compared with price index, changes in GDP have a greater impact on the price of 
steel products because the magnitude of the coefficient is bigger $(0.369883)$ and the significance level higher. As pointed out in the previous text, the rapid increase of China's GDP is connected with the fact that China was in a growth stage. Consequently the consumption of steel products increased rapidly so we observe an increase in steel products prices. Furthermore, China's recent economic growth has been scale expanding, which increases the demand of steel products. For this reason, it is not strange that the change of GDP has contributed to the increase of the price of steel products positively from 1978 to 1998.

A real appreciation of the domestic currency will lead to a decrease of steel products prices because of the lower demand due to a relatively higher price. In our regression here we are not testing the relationship between Chinese exchange rates and its steel products prices. The exchange rate data in our regression reflects the variations of Japanese Yen against the US dollar. Japan is a strong competitive neighbor of China so its economic status affects China significantly as we discussed in part 3.3. Higher exchange rates denote a depreciation of the Japanese Yen against the US dollar so the relative price of Japanese steel products becomes lower which stimulates the demand for their products and consequently decreases the demand for Chinese steel products and Chinese steel products prices. The negative coefficient on $\varepsilon$ here is consistent with the theoretical prediction which support our analysis. Again the effect is not very significant but these results still give us some information when we examine the process of steel products prices and as Chinese markets become more open, the value of this coefficient can be expected to increase further. 
As interest rates go up the cost of storage rises and people may substitute investment with savings so we expect a lower demand for intermediate commodities which of course gives us a lower steel price. But contrary to analytical expectations, the estimated value of the coefficient on interest rate $\gamma$ is positive. We noticed that this positive coefficient is not statistically significant so it does not reject our theory at a 0.05 significant level. You still might wonder why these results do not react as expected? Possibly because China's interest rate is not formed in the market, instead the government decides it. So the interest rate has nothing to do with the demand and the supply of money. The elasticity of the supply of social capital to interest rate is small. This offers one explanation for the abnormally positive sign here.

Imports and exports influence the price of steel products through increases or decreases in demand for steel products. The estimated value of $\Delta E_{t}$ is negative in the regression equation, as predicted. The very encouraging thing is that this coefficient is significant at 0.01 level which tells us that imports and exports play a dominant role in explaining Chinese steel product prices during the period 1978-1998. Compared with other factors we examined, this result suggests that one should focus on imports and exports factors to explain changes in Chinese steel products prices. This offers both the Chinese government and the steel industry enterprises important information when they make policy decisions. One might argue that the magnitude of the coefficient is very small, only 0.034783 which is not significantly different from zero. One explanation is that the Chinese government controlled the price of steel products during the years from 1978 to 1998 and under such circumstances, the increase of exports leads to a black 
market for steel products and the increase of imports leads to the increase of the stock of steel products so the effect has been undermined. This however does not change the negative significant relationship between import/export ratio and steel prices.

On the basis of a detailed analysis of the factors that influence the price of steel products during a recent 20-year period, a price model for steel products has been developed. Such a model can help the producers and consumers of steel products forecast the price of steel products, so that they can adjust their demand or the supply for the steel products accordingly. At the same time, similar methods can be used to analyze the factors influencing products in other sectors. Price models of products such as agriculture goods, household electrical appliances, etc can be developed. Such research could no doubt benefit China's economic development. However, practical research in this field is rare in China at this time.

\section{Conclusion}

The result of the research in this thesis is only suitable for countries that are market oriented. There are a lot of tariff and non-tariff trade barriers in China's international trade and China does not have a perfect market economy at this time. Under a market economy, the factors, which influence the price of steel products, operate primarily through the forces of demand and supply. The supply function for steel products will not change drastically during a short period. China is not quite such a country right now so we see the insignificant effect of most of these factors. From a 
longer point of view, with the trend toward globalization, China's market will merge with the world market and become more market oriented. Then China's steel companies will become price acceptors in the world steel market. Research of the prices of China's steel products will focus on the factors influencing the price of steel products of main steel suppliers and demanders of the world. The research in this thesis provides some guidance for developing China's steel industry and the whole economy through the pricing model suggested here.

Given the economic status in China for the time being (middle stage of industrialization ) together with our theoretical and empirical research results, we suggest that cooperation must exist in the steel industry. An association to the steel industry could be formed which would consist of leaders of main steel companies and representatives from the government. The association would set a price, which is a little bit higher than the market price. This would avoid the economic instability caused by the fierce competition. The strategy could also increase the producer surplus. From the increased profit generated by this procedure, the government could set a ratio such that each company must use a certain portion of its total revenue to introduce or develop new technology. More importantly the government should do more to create a good economic environment such as reforming the property-rights system, perfecting the social security system, etc. Well-defined property rights would help clear the barriers which hinder the firms' ability to merge and make acquisitions. Such mergers would enhance the firms' ability to improve product quality, reduce costs, enhancing the international competitiveness of China's steel industry.

The research has some limits. First, in choosing variables, five main factors that 
influence the price of steel products in China we've chosen, according to the analysis of other researchers and experience. Other factors that may influence the price of steel products are not included in the research. For example the price of substitutes and complementary products are neglected. Second, only a twenty-year period of data was included in the regressions. The results may be limited because of the limited number of variables considered and the limited time period. Certainly more work needs to be done in this research area. 


\section{Table and Figures}

\begin{tabular}{|c|c|c|c|c|c|c|c|c|}
\hline Year & $\begin{array}{l}\text { Steel Price } \\
\text { Indexes }\end{array}$ & $\begin{array}{l}\text { Total price } \\
\text { level }\end{array}$ & $\begin{array}{l}\text { GNP(Billio } \\
\text { n Yuan) }\end{array}$ & $\begin{array}{l}\text { Exchange } \\
\text { Rates(JY/\$) }\end{array}$ & $\begin{array}{l}\text { Interest } \\
\text { Rates(\%) }\end{array}$ & $\begin{array}{l}\text { Import(x10 } \\
000 \mathrm{MT})\end{array}$ & $\begin{array}{l}\text { Export(x10 } \\
\text { 000MT) }\end{array}$ & $\mathrm{I} / \mathrm{J}$ \\
\hline 78 & 100.00 & 100.00 & 358.81 & 208.45 & 5.04 & 863.75 & 33.26 & 25.9696 \\
\hline 79 & 101.60 & 103.56 & 399.81 & 221.97 & 5.04 & 847.25 & 36.80 & 23.0231 \\
\hline 80 & 107.90 & 107.40 & 447.01 & 225.83 & 5.04 & 500.64 & 39.77 & 12.5884 \\
\hline 81 & 109.80 & 109.76 & 477.30 & 222.02 & 5.04 & 331.85 & 61.72 & 5.3767 \\
\hline 82 & 110.90 & 110.00 & 519.30 & 249.70 & 7.20 & 393.78 & 110.11 & 3.5762 \\
\hline 83 & 112.40 & 111.27 & 580.90 & 237.93 & 7.20 & 977.97 & 49.23 & 19.8653 \\
\hline 84 & 116.70 & 116.26 & 696.20 & 238.97 & 7.20 & 1331.45 & 20.33 & 65.4919 \\
\hline 85 & 133.30 & 126.73 & 855.70 & 235.18 & 7.92 & 1963.49 & 18.12 & 108.3604 \\
\hline 86 & 143.20 & 132.80 & 969.63 & 168.57 & 7.92 & 1742.23 & 19.74 & 88.2589 \\
\hline 87 & 153.20 & 139.55 & 1130.10 & 142.87 & 7.92 & 1174.94 & 27.73 & 42.3707 \\
\hline 88 & 176.80 & 156.08 & 1406.82 & 128.32 & 9.00 & 851.08 & 15.88 & 53.5945 \\
\hline 89 & 214.00 & 170.06 & 1599.33 & 138.34 & 11.34 & 819.72 & 78.07 & 10.4998 \\
\hline 90 & 236.00 & 180.85 & 1769.53 & 145.09 & 9.72 & 368.26 & 208.98 & 1.7622 \\
\hline 91 & 269.50 & 191.18 & 2023.63 & 134.12 & 8.64 & 332.59 & 329.33 & 1.0099 \\
\hline 92 & 307.80 & 200.93 & 2403.62 & 126.43 & 8.64 & 710.00 & 326.70 & 2.1732 \\
\hline 93 & 335.00 & 292.00 & 3456.05 & 110.69 & 10.17 & 3026.00 & 112.00 & 27.0179 \\
\hline 94 & 384.00 & 314.00 & 4653.29 & 101.26 & 10.17 & 2282.84 & 174.35 & 13.0934 \\
\hline 95 & 427.00 & 331.00 & 5727.73 & 94.12 & 12.00 & 1397.23 & 592.82 & 2.3569 \\
\hline 96 & 390.00 & 326.00 & 6243.20 & 109.42 & 10.53 & 1598.38 & 421.53 & 3.7919 \\
\hline 97 & 375.00 & 307.00 & 6786.40 & 121.81 & 8.64 & 1322.45 & 461.89 & 2.8631 \\
\hline 98 & 346.00 & 293.00 & 7315.80 & 130.73 & 7.08 & 1242.00 & 357.00 & 3.4790 \\
\hline
\end{tabular}




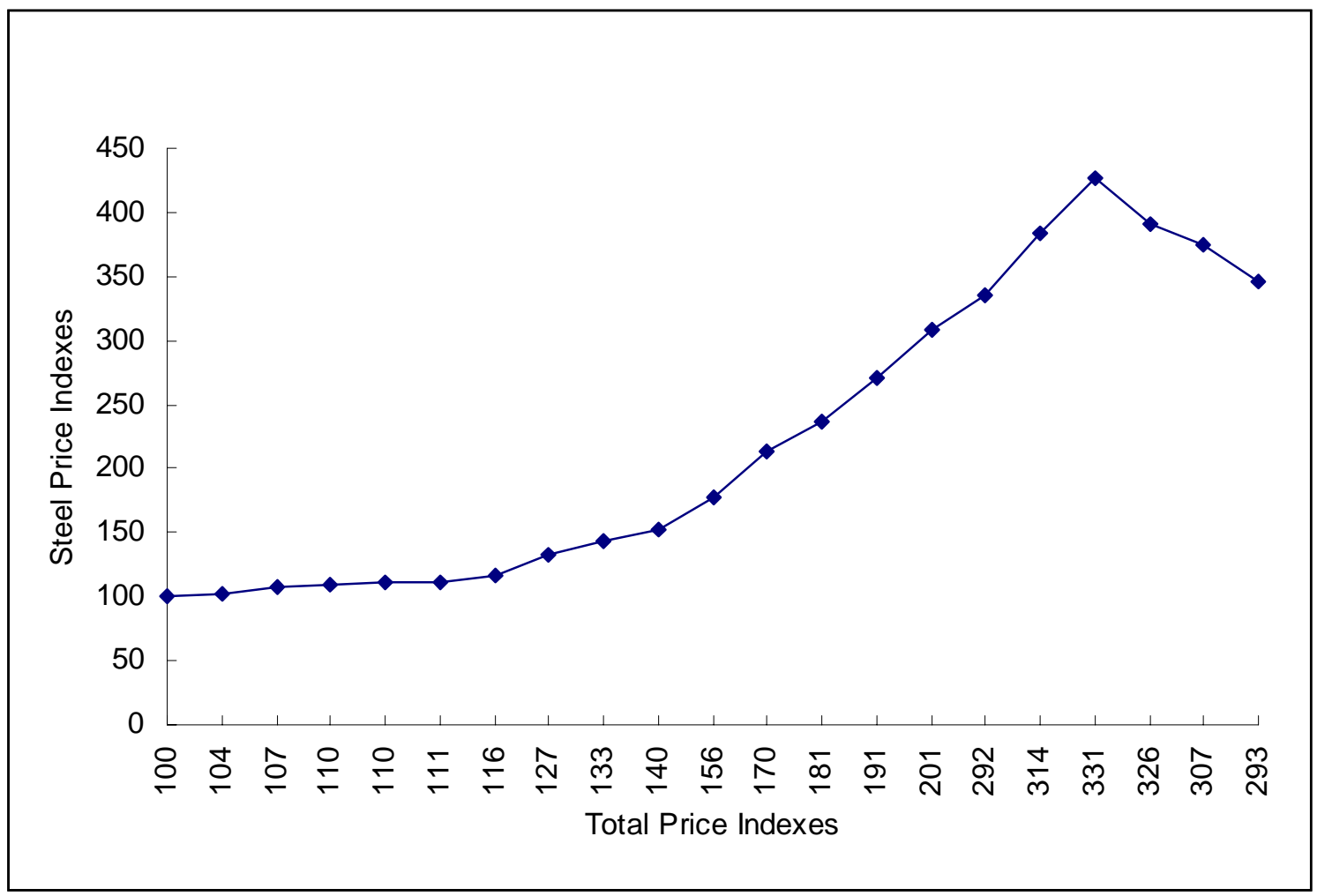

Fig. 3-1

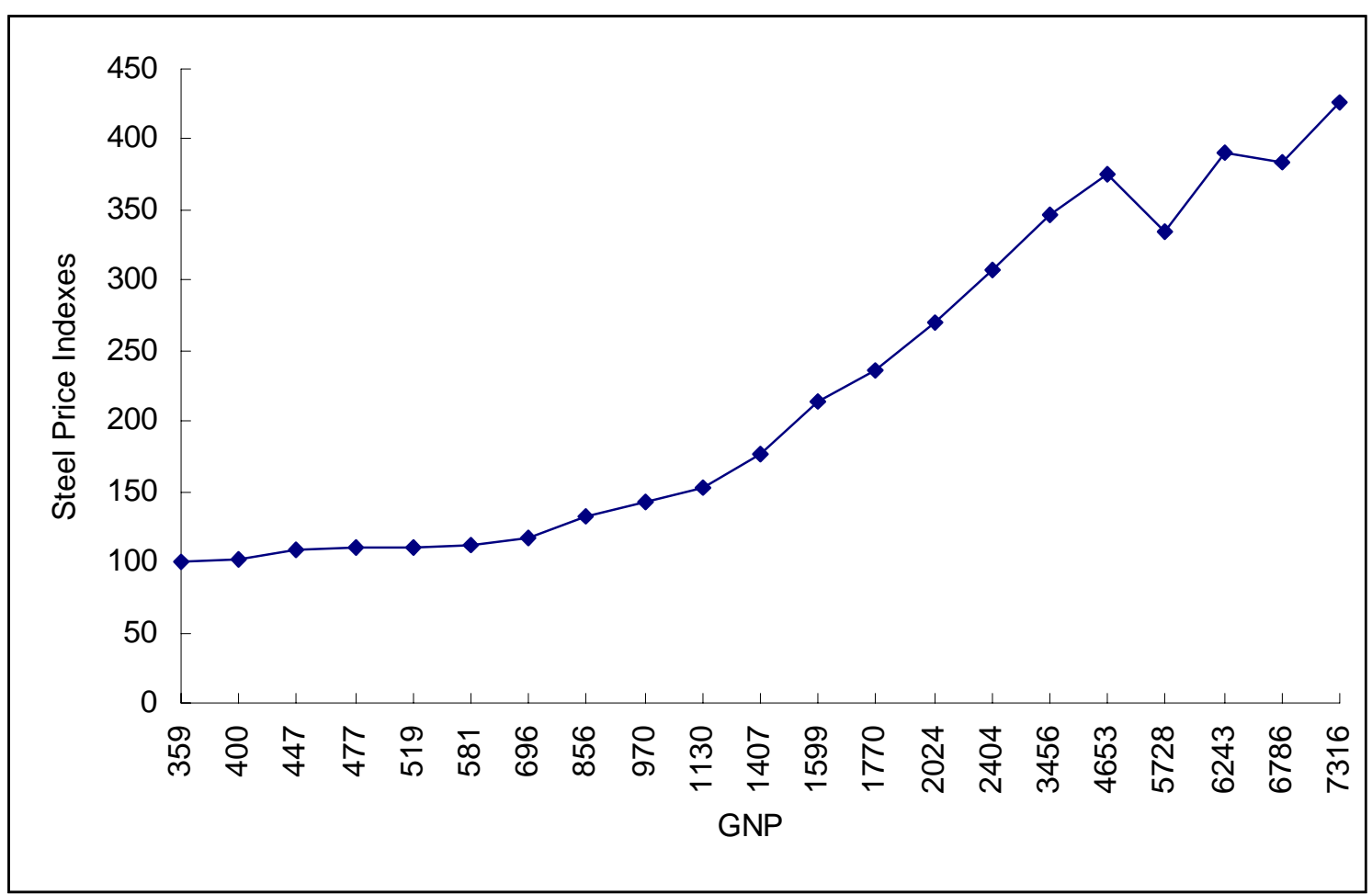

Fig.3-2 


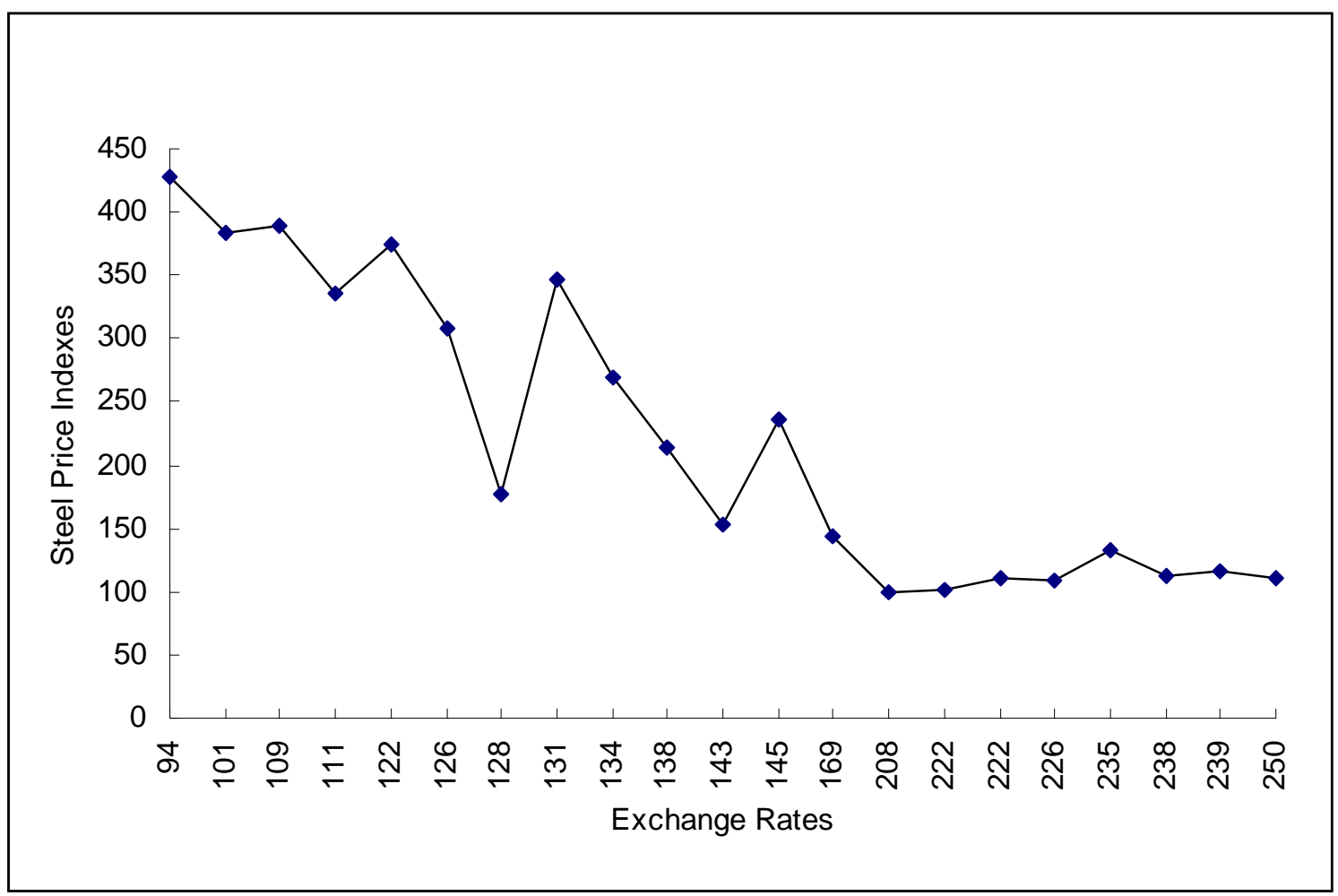

Fig.3-3

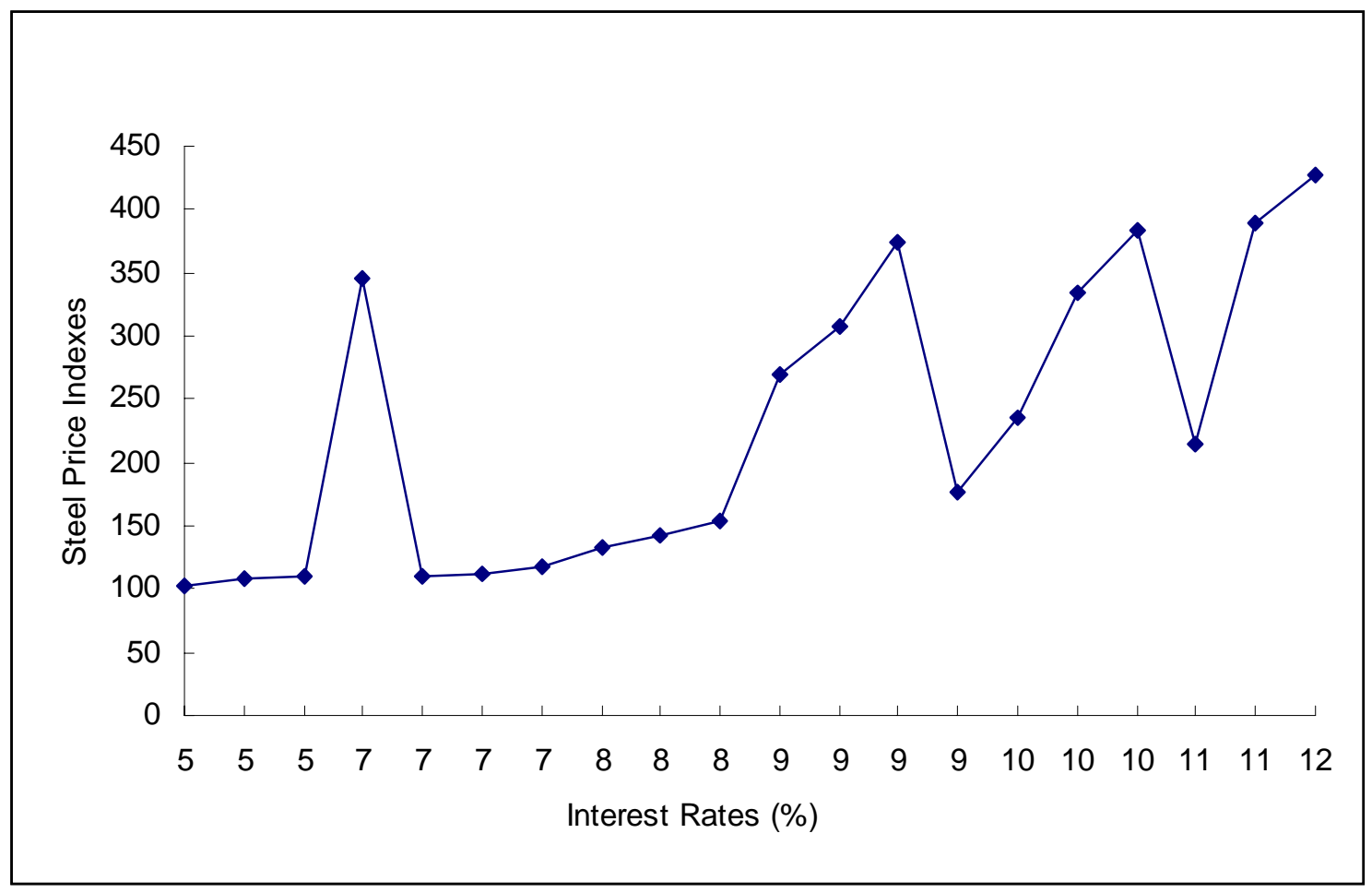

Fig.3-4 
Fig.3-6
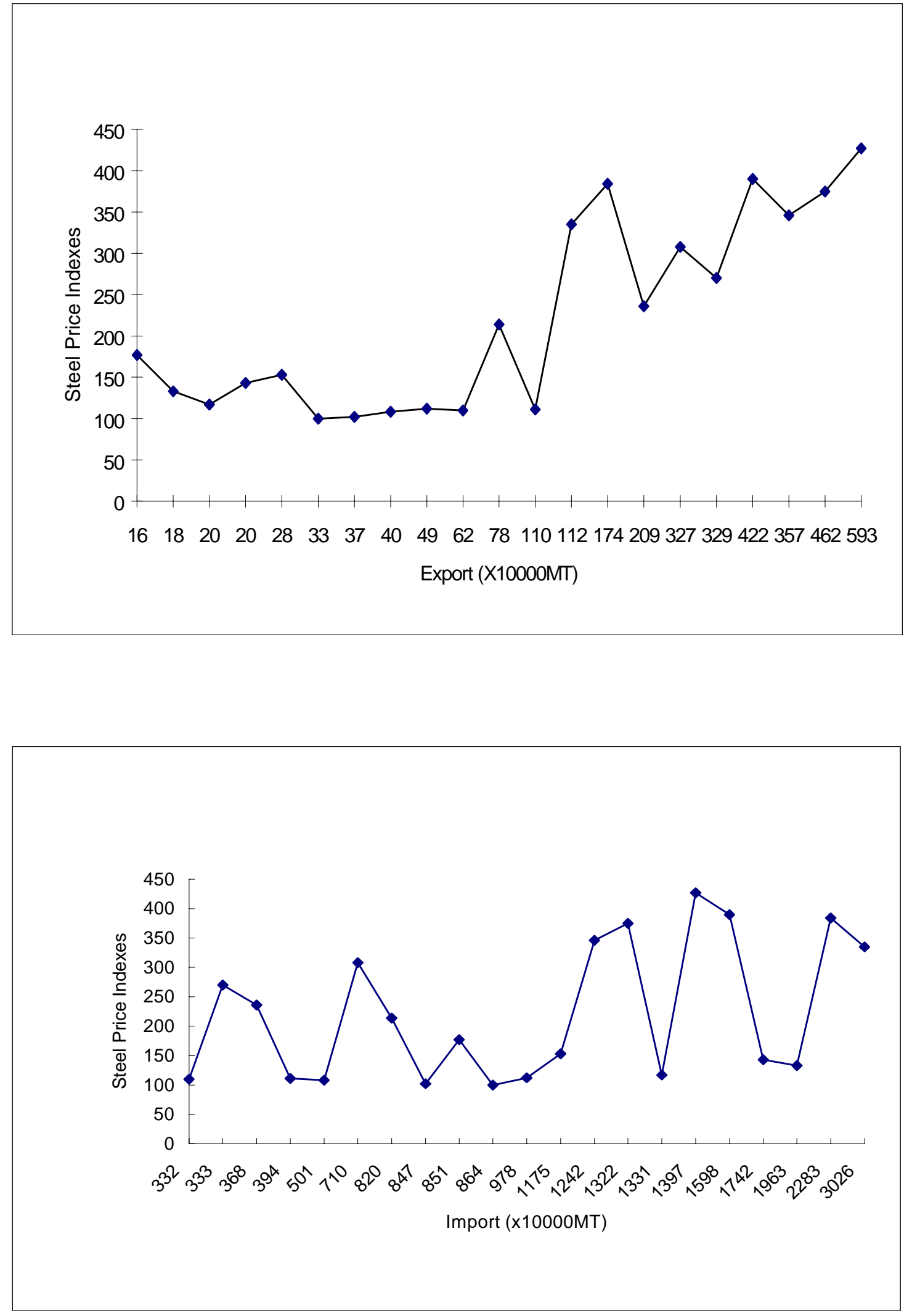

Fig.3-5 


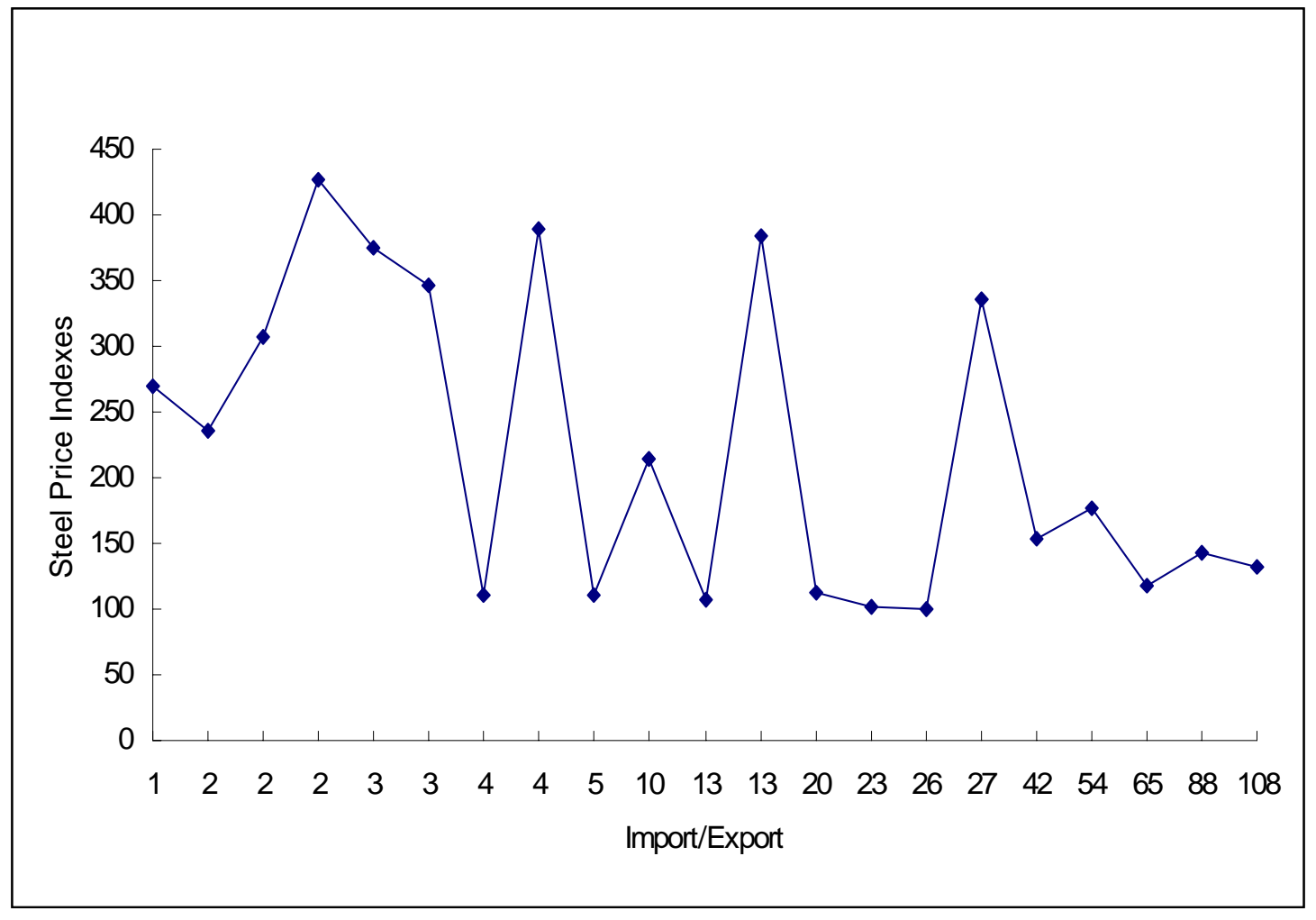

Fig.3-7 


\section{References}

1.Angus Deaton, On the behavior of commodity prices, Review of Economic Studies, 1992, v59, 1-23.

2. China Metallurgical Department: China Steel Statistics (1998)

3. China Statistic Year Book (1998)

4. Eduardo Borensztein \& Carmen M. Reinhart, The macroeconomic determinants of commodity prices, International Monetary Fund, v41, June 1994, 236-61.

5. Fisher, F. and Shell, K., 1972. The Economic Theory of Price Indices: Two Essays on the Effects of Taste, Quality, and Technological Change. New York: Academic Press.

6. Gorman, W.M., 1980. A possible procedure for analyzing quality differentials in the egg market. Review of Economic Studies 47, 843-56

7. Hua Ping, On primary commodity prices: the impact of macroeconomic monetary shocks, Journal of Policy Modeling, v20, n6, December,1998, 767-90.

8. Katarina Juselius, Domestic and foreign effects on prices in an open economy: the case of Denmark, Journal of Policy Modeling, 1992, v14,404-28.

9. William T. Hogan, S. J: Economic history of the iron and steel industry in the United States

10. Crandall Robert W.: The U.S Steel Industry in Recent Crisis, The Brookings Institution, 1981

11. Raiyu Yin: The facing problems in steel products, Price Theory and Practice 1995-1, page $21-25$ 
12. Survey of Current Business: page S1-S39

13. John M. Clapp and Carmelo Giaccotto: Estimating Price Indices for Residential Property P300-306

14. Griliches, Z., 1971. Price Indexes and quality Change: Studies in New Methods Measurement. Cambridge, Mass.: Harvard University Press.

15. Braithwait, S.D., 1980. The substitution bias of the Laspeyres price index: an analysis using estimated cost-of living indexes. American Economic Review 70, 64-77 